\title{
Evaluating Translation in Terms of Equivalence and Balance
}

\author{
Dr. Yasin Aslan \\ Sinop University, Sinop, Turkey
}

\begin{abstract}
The comparison of texts in different languages involves a theory of equivalence. Equivalence is one of the central issues in translation though its definition, relevance, and applicability within the field of translation theory have brought about controversy among scholars, and many different theories of the concept of equivalence have been elaborated within this field in the past few decades. The purpose of this study is to make a general revision of the theory of equivalence supported by Vinay, Nida, Jakobson, Taber, and Baker, who have studied equivalence with regard to the translation process, using different approaches, and have come up with beneficial ideas on this subject. Their theories can be substantially classified into three groups. As a matter of fact, once a message is transferred from the SL to TL, the translator is dealing with two different cultures at the same time. This particular aspect seems to have been taken into consideration by the second group of theorists who regard translation equivalence as being essentially a transfer of the message from the SC to the TC and a pragmatic/semantic or functionally oriented approach to translation. Finally, equivalence is used because many translators are accustomed to it.
\end{abstract}

Keywords: translation, foreign language, equivalence, balance, text

\section{Introduction}

Translation has been much analyzed and talked about in recent years. Literal versus free translation has been discussed for ages. The translators who have been more faithful to the content, the message, and the spirit than the form have favoured literal translation while others have been in favour of free and natural translation. Several conclusions have come up regarding its nature, the hindrances a language learner faces during translation, traits of a translator and the process that is to be followed. Language can be misused unintentionally while using a particular expression, the intentions of the translator could be innocent; however, the actual meaning of the expression in the targeted language could be offensive. Reading the original language poses a problem to inexperienced or unskilled translators. Also, the translator may have difficulty in comprehending the language due to lack of proficiency in that language or complexity of the language or the personal interpretation of the translator. The translator usually brings in his/her own ideas and experiences while interpreting a text or document, which potentially harm the document's accuracy, intent, and effect. On the other hand, the translator should ideally be accustomed to that language to ensure comprehensive translation of the content, complete with colloquial understanding of expressions, humor, slangs, hidden meanings, culturally significant content, etc.

A translator should analyze the source text to choose the right method. The translator must determine the one he/she will put the emphasis on and decide the method on the ground of his priorities. Different methods

Dr. Yasin Aslan, assistant professor, doctor, Foreign Languages Department, Sinop University. 
can be applied for the same text in terms of the primacy. For instance, when translating a text written for children, a different method will be applied from the one for the intellectuals or laymen.

A good translator should be aware of all the characteristics of the language. Besides, a translator must study the intention of the text, the readership of the target text, and his own objective. Contextual understanding of the document is extremely important. There are some rare words whose meanings fade away, not just the general public but also the dictionaries. The translator should have enough common sense and intuition to come up with the closest possible word for it. Only a thorough understanding of the language and the field of translation warrants such advanced skills. There are several rules and cultural differences to be considered in both languages. It is difficult to express exactly the same meaning in another language at times. There are sometimes no equivalents for certain words or expressions. The most a translator can do is come up with the next best alternative word. All these problems that are faced during the translation process can be dealt with experience, taking up a variety of projects, and through a constant improvement in foreign language skills.

Cakir (2016) states that an event or a quality can be described more comprehensively by means of figurative expressions rather than using literal language as the traits of the animate can be used for the inanimate and vice-versa. That is why a car may "lie down and die", the wind "kisses" our cheeks, the waves are "angry" and "roar", the cliffs are "treacherous", the mountains "look down" on the sea, the machine guns "spit", revolvers "bark", volcanos "vomit fire" and engines "cough".

Gokturk (2016) mentions the enthusiasm and emotions of the poet George Chapman in the original lines:

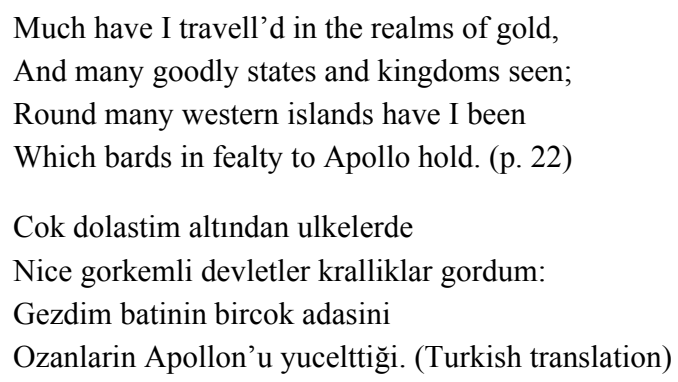

According to Uzbay (2015), bilateral translation is a technique by which a learner can understand the words, grammar rules, and expressions in a text as in the following example:

In my dream I was in a large city. It was very big and very dark. The city seemed like New York but it didn't look like the real New York. I was in a friend's apartment. While I was in the apartment, I was comfortable. After a few minutes, I left it and went out on the street alone. I walked for a while. Then I realized I was lost. I couldn't find my friend's apartment again. I started to feel uneasy. I tried to return to the apartment but all the streets looked unfamiliar and I didn't know my friend's address. I began to feel anxious. (Original text, p. 165)

Ruyamda buyuk bir sehirdeydim. Cok buyuk ve cok karanlikti. Sehir New York'a benziyordu ama gercek New York gibi değildi. Bir arkadasimin dairesindeydim. Dairedeyken rahattim. Birkac dakika sonar daireden ayrilip tek basıma caddeye ciktim. Bir sure yurudum. Sonra kayboldugumu anladim. Arkadaşimin dairesini bir daha bulamadim. Kendimi huzursuz hissetmeye basladim. Daireye donmeye çalistim ama butun caddeler bana yabanci gibiydi ve arkadasimin adresini de bilmiyordum. Endişelenmeye basladim. (Turkish translation)

\section{Definition of Equivalence in Translation}

Vinay and Darbelnet view equivalence-oriented translation as a procedure which "replicates the same situation as in the original, whilst using completely different wording" (quoted in Kenny, 1998, p. 342). They 
also suggest that, if this procedure is applied during the translation process, it can maintain the stylistic impact of the SL text in the TL text. According to them, equivalence is therefore the ideal method when the translator has to deal with proverbs, idioms, clichés, nominal or adjectival phrases, and the onomatopoeia of animal sounds.

With regard to equivalent expressions between language pairs, Vinay and Darbelnet claim that they are acceptable as long as they are listed in a bilingual dictionary as "full equivalents" (ibid., p. 255). However, later they note that glossaries and collections of idiomatic expressions "can never be exhaustive" (ibid., p. 256). They conclude by saying that "the need for creating equivalences arises from the situation, and it is in the situation of the SL text that translators have to look for a solution" (ibid., p. 255). Indeed, they argue that even if the semantic equivalent of an expression in the SL text is quoted in a dictionary or a glossary, it is not enough, and it does not guarantee a successful translation. They provide a number of examples to prove their theory, and the following expression appears in their list: take one is a fixed expression which would have as an equivalent French translation Prenez-enun. However, if the expression appeared as a notice next to a basket of free samples in a large store, the translator would have to look for an equivalent term in a similar situation and use the expression Échantillongratuit (ibid., p. 256).

\section{The Concept of Equivalence in Difference}

Roman Jakobson's study of equivalence gave new impetus to the theoretical analysis of translation since he introduced the notion of "equivalence in difference". On the basis of his semiotic approach to language and his aphorism "there is no signatum without signum" (Jakobson, 1959, p. 232), he suggests three kinds of translation:

- Intralingual (within one language, i.e., rewording or paraphrase);

- Interlingual (between two languages);

- Intersemiotic (between sign systems).

Jakobson claims that, in the case of interlingual translation, the translator makes use of synonyms in order to get the ST message across. This means that in interlingual translations there is no full equivalence between code units. According to his theory, "translation involves two equivalent messages in two different codes" (ibid., p. 233). Jakobson goes on to say that from a grammatical point of view languages may differ from one another to a greater or lesser degree, but this does not mean that a translation cannot be possible, in other words, that the translator may face the problem of not finding a translation equivalent. He acknowledges that "whenever there is deficiency, terminology may be qualified and amplified by loanwords or loan-translations, neologisms or semantic shifts, and finally, by circumlocutions" (ibid., p. 234). Jakobson provides a number of examples by comparing English and Russian language structures and explains that in such cases where there is no a literal equivalent for a particular ST word or sentence, then it is up to the translator to choose the most suitable way to render it in the TT.

There are some resemblances between Vinay and Darbelnet's translation approaches and Jakobson's theory of translation. Both theories emphasize the fact that the translator can focus on other procedures such as loan-translations, neologisms. Vinay and Darbelnet regard the translation as something which can always be carried out from one language to another, irrespective of the cultural or grammatical differences between ST and TT. On the other hand, Jakobson's theory is basically dependent on a semiotic approach. 


\section{Formal Correspondence and Dynamic Equivalence}

There are two different types of equivalence, namely formal equivalence and dynamic equivalence. Formal correspondence "focuses attention on the message itself, in both form and content", unlike dynamic equivalence which is based upon "the principle of equivalent effect" (Nida, 1964, p. 159). Formal correspondence is comprised of a TL item which represents the closest equivalent of a SL word or phrase. Nida and Taber clarify that there are not always formal equivalents between language pairs. Accordingly, they assert that these formal equivalents should be utilized wherever possible if the translation aims at achieving formal rather than dynamic equivalence. The use of formal equivalents might at times have serious implications in the TT since the translation will not be easily understood by the target audience (Fawcett, 1997). Nida and Taber themselves assert that "Typically, formal correspondence distorts the grammatical and stylistic patterns of the receptor language, and hence distorts the message, so as to cause the receptor to misunderstand or to labor unduly hard" (ibid., p. 201).

Dynamic equivalence is defined as a translation principle according to which a translator seeks to translate the meaning of the original in such a way that the TL wording will trigger the same impact on the TC audience as the original wording did upon the ST audience. They argue that,

Frequently, the form of the original text is changed; but as long as the change follows the rules of back transformation in the source language, of contextual consistency in the transfer, and of transformation in the receptor language, the message is preserved and the translation is faithful. (Nida \& Taber, 1982, p. 200)

It can easily be seeb that Nida is in favour of the application of dynamic equivalence. This is relatively understandable if we take into account the context of the situation in which Nida was dealing with the translation phenomenon, that is to say, his translation of the Bible. Thus, the product of the translation process, that is the text in the TL, must have the same impact on the different readers it was addressing. Only in Nida and Taber's edition is it clearly stated that "dynamic equivalence in translation is far more than mere correct communication of information" (ibid., p. 25).

Despite using a linguistic approach to translation, Nida is much more interested in the message of the text or, in other words, in its semantic quality. He therefore strives to make sure that this message remains clear in the target text.

\section{The Introduction of Translation Shifts}

Catford's approach to translation equivalence clearly differs from that adopted by Nida since Catford had a preference for a more linguistic-based approach to translation and this approach is based on the linguistic work of Firth and Halliday. His main contribution in the field of translation theory is the introduction of the concepts of types and shifts of translation. Catford proposed very broad types of translation in terms of three criteria:

(1) The extent of translation (full translation vs. partial translation);

(2) The grammatical rank at which the translation equivalence is established (rank-bound translation vs. unbounded translation);

(3) The levels of language involved in translation (total translation vs. restricted translation).

In rank-bound translation an equivalent is sought in the TL for each word, or for each morpheme encountered in the ST. In unbounded translation equivalences are not tied to a particular rank, and we may 
additionally find equivalences at sentence, clause, and other levels. Hence, a formal correspondence could be said to exist between English and French if relations between ranks have approximately the same configuration in both languages, as Catford claims they do. One of the problems with formal correspondence is that, despite being a useful tool to employ in comparative linguistics, it seems that it is not really relevant in terms of assessing translation equivalence between ST and TT. For this reason we now turn to Catford's other dimension of correspondence, namely textual equivalence which occurs when any TL text or portion of text is "observed on a particular occasion...to be the equivalent of a given SL text or portion of text" (ibid., p. 27). He implements this by a process of commutation, whereby "a competent bilingual informant or translator" is consulted on the translation of various sentences whose ST items are changed in order to observe "what changes if any occur in the TL text as a consequence" (ibid., p. 28).

As far as translation shifts are concerned, Catford defines them as "departures from formal correspondence in the process of going from the SL to the TL" (ibid., p. 73). Catford argues that there are two main types of translation shifts, namely level shifts, where the SL item at one linguistic level (e.g., grammar) has a TL equivalent at a different level (e.g., lexis), and category shifts which are divided into four types:

(1) Structure-shifts, which involve a grammatical change between the structure of the ST and that of the TT;

(2) Class-shifts, when a SL item is translated with a TL item which belongs to a different grammatical class, i.e., a verb may be translated with a noun;

(3) Unit-shifts, which involve changes in rank;

(4) Intra-system shifts, which occur when "SL and TL possess systems which approximately correspond formally as to their constitution, but when translation involves selection of a non-corresponding term in the TL system" (ibid., p. 80), for instance, when the SL singular becomes a TL plural. Catford was very much criticized for his linguistic theory of translation. One of the most scathing criticisms came from Snell-Hornby (1988), who argued that Catford's definition of textual equivalence is "circular", his theory's reliance on bilingual informants "hopelessly inadequate", and his example sentences "isolated and even absurdly simplistic" (ibid., pp. 19-20).

\section{The Elaboration of Overt and Covert Translation}

House (1977) is in favour of semantic and pragmatic equivalence and argues that ST and TT should match one another in function. House suggests that it is possible to characterize the function of a text by determining the situational dimensions of the ST. In fact, according to her theory, every text is in itself is placed within a particular situation which has to be correctly identified and taken into account by the translator. After the ST analysis, House is in a position to evaluate a translation; if the ST and the TT differ substantially on situational features, then they are not functionally equivalent, and the translation is not of a high quality. In fact, she acknowledges that "a translation text should not only match its source text in function, but employ equivalent situational-dimensional means to achieve that function" (ibid., p. 49).

Central to House's discussion is the concept of overt and covert translations. In an overt translation the TT audience is not directly addressed and there is therefore no need at all to attempt to recreate a "second original" since an overt translation "must overtly be a translation" (ibid., p. 189). By covert translation, on the other hand, is meant the production of a text which is functionally equivalent to the ST. House also argues that in this type of translation the ST "is not specifically addressed to a TC audience" (ibid., p. 194). 
House (ibid., p. 203) sets out the types of ST that would probably yield translations of the two categories. An academic article, for instance, is unlikely to exhibit any features specific to the SC; the article has the same argumentative or expository force that it would if it had originated in the TL, and the fact that it is a translation at all need not be made known to the readers. It is clear that in this latter case, which is an instance of overt translation, functional equivalence cannot be maintained, and it is therefore intended that the ST and the TT function differently.

House's theory of equivalence in translation seems to be much more flexible than Catford's. In fact, she gives authentic examples, uses complete texts and, more importantly, she relates linguistic features to the context of both source and target text.

\section{Baker's Approach to Translation Equivalence}

New adjectives have been assigned to the notion of equivalence (grammatical, textual, pragmatic equivalence, and several others) and made their appearance in the plethora of recent works in this field. An extremely interesting discussion of the notion of equivalence can be found in Baker (1992) who seems to offer a more detailed list of conditions upon which the concept of equivalence can be defined. She distinguishes between:

(1) Equivalence that can appear at word level and above word level, when translating from one language into another. Baker acknowledges that, in a bottom-up approach to translation, equivalence at word level is the first element to be taken into consideration by the translator. Baker gives a definition of the term word since it should be remembered that a single word can sometimes be assigned different meanings in different languages and might be regarded as being a more complex unit or morpheme. This means that the translator should pay attention to a number of factors when considering a single word, such as number, gender and tense (ibid., pp. 11-12);

(2) Grammatical equivalence, when referring to the diversity of grammatical categories across languages. She notes that grammatical rules may vary across languages and this may pose some problems in terms of finding a direct correspondence in the TL. Amongst these grammatical devices which might cause problems in translation Baker focuses on number, tense and aspects, voice, person and gender;

(3) Textual equivalence, when referring to the equivalence between a SL text and a TL text in terms of information and cohesion. It is up to the translator to decide whether or not to maintain the cohesive ties as well as the coherence of the SL text. His or her decision will be guided by three main factors, that is, the target audience, the purpose of the translation and the text type;

(4) Pragmatic equivalence, when referring to implicatures and strategies of avoidance during the translation process. Implicature is not about what is explicitly said but what is implied. Therefore, the translator needs to work out implied meanings in translation in order to get the ST message across. The role of the translator is to recreate the author's intention in another culture in such a way that enables the TC reader to understand it clearly.

\section{Conclusion}

The idea of equivalence is certainly one of the most controversial fields in translation theory. The term has led to heated arguments within the field of translation studies. This term has been analyzed, evaluated, and extensively argued from different points of view and has been approached from a variety of different 
perspectives. The first discussions of the notion of equivalence in translation started the further elaboration of the term by contemporary theorists. Even the brief outline of the issue given above shows its significance within the framework of the theoretical reflection on translation. The difficulty in defining equivalence seems to result in the impossibility of having a universal approach to this goal.

\section{References}

Baker, M. (1992). In other words: A coursebook on translation. London: Routledge.

Cakir, A. (2005). Translation methods. Journal of Selcuk University Social Sciences Institution, 14, 237-244.

Cakir, A. (2016). Raising awareness on the Turkish learners of English about the arbitrary nature of figurative expressions. European Journal of Multidiscipliary Studies, 1(2).

Catford, J. C. (1965). A linguistic theory of translation: An essay on applied linguistics. London: Oxford University Press.

Fawcett, P. (1997). Translation and language: Linguistic theories explained. Manchester: St. Jerome Publishing.

Gokturk, A. (2016). Translation: Language of languages (12th ed.). Istanbul: Yapi Kredi Publications.

House, J. (1977). A model for translation quality assessment. Tübingen: Gunter Narr.

Jakobson, R. (1959). On linguistic aspects of translation. In R. A. Brower (Ed.), On translation (pp. 232-239). Cambridge, MA: Harvard University Press.

Kenny, D. (1998). Equivalence. In M. Baker (Ed.), The Routledge encyclopaedia of translation studies (pp. 77-80). London and New York: Routledge.

Leonardi, V. (2000). Equivalence in translation: Between myth and reality. Translation Journal, 4(4).

Nida, E. A. (1964). Towards a science of translating. Leiden: E. J. Brill.

Nida, E. A., \& Taber, C. R. (1969/1982). The theory and practice of translation. Leiden: E. J. Brill.

Uzbay, E. (2015). Proficiency exam (3rd ed.). Istanbul: Cinius Publications.

Vinay, J. P., \& Darbelnet, J. (1995). Comparative stylistics of French and English: A methodology for translation. (J. C. Sager \& M. J. Hamel, Trans.). Amsterdam / Philadelphia: John Benjamins. 